NBER WORKING PAPER SERIES

\title{
SHOULD WE ORGANIZE? EFFECTS OF FACULTY UNIONISM ON ACADEMIC COMPENSATION*
}

Richard B. Freeman

Working Paper No.

\author{
NATIONAL BUREAU OF ECONOMIC RESEARCH \\ 1050 Massachusetts Avenue \\ Cambridge MA 02138 \\ November 1978
}

* Supported by the Ford Foundation. Casey Ichniowski put together the data tapes for this research and performed much of the original analysis. Eric Seiler helped complete the research work. Maryse Eymonerie of the AAUP helped the project by providing data and advice. The research reported here is part of the NBER's research program in labor studies. Any opinions expressed are those of the author and not those of the National Bureau of Economic Research. 


\title{
Should We Organize? Effects of Faculty Unionism
}

on Academic Compensation

\begin{abstract}
This paper vses the American Association of University Professors surveys for the period 1965 to 1976 to examine the effect of faculty unionism on faculty pay. It compares estimated effects of unionism on compensation from cross-section regressions of faculty pay on union organization and from a longitudinal model designed to correct cross-section estimates for "unobserved characteristics" of schools that are correlated with unionism. The major findings are that: 1. unionism raises faculty pay but that the extent of the effect varies greatly by estimating model and time period covered; 2. the years a school has been organized has a stronger effect on pay than the standard 0-1 union dumy variable; 3. unionism raises the fringe benefit share of compensation; 4. the estinated coefficient on faculty unionism in cross-section regressions overstates the union impact because unionized schools tend to have been higher paying even before organization.
\end{abstract}

Richard B. Freeman N.B.E.R. 1050 Massachusetts Avenue Cambridge, MA 02138 (617) 868-3915 
In 1964 virtually no college or university faculty in the United States was represented by a trade union. In 1977 over 300 institutions were organized, constituting over 10 percent of institutions of higher education. ${ }^{1}$ Faculty unions were among the most rapidly growing in the economy, scoring considerably better than the average in winning representation. 2 How have faculty unions affected the economic position of academics? Which components of the compensation structure have been most influenced by unionism? Have the economic effects of unionism changed over time as the academic market place has deteriorated?

This paper examines these and related questions regarding the effects of faculty unionism on compensation with detailed longitudinal data files from the American Association of University Professors (AAUP). In contrast to previous work on the economic effects of faculty unionisto, which have been limited to small samples and obtained inconclusive of ten contradictory results (Birnbaum, Morgan-Kearney, Brown-Stone) ${ }^{3}$, this study expoits the full set of AAUP compensation data to estimate union effects on longitudinal as well as cross-section data. The paper finds a substantial union effect which, however, differs over time and among institutions, and whose magnitude varies with the model used in the estimation procedure. In cross-section calculations, faculty unionism has a significant effect on compensation which differs among institutions, rank of faculty, and over time; and which is more pronounced on fringe benefits than on straight-time pay. In a longitudinal model, which takes account of the possible selectivity bias in institutions that organize and of the effect of school characteristics on the growth of compensation, estimates of the magnitude of the union compensation effect vary from small to fairly sizcablc, depending on the before union compensation used to control for the omitted factor. In both the cross-section and longitudinal analyses, institutions that have been organized for longer periods of 
time appear to have been more affected by unions than those organized more recently.

Section one of the paper sketches briefly the institutional background of faculty unionism. Section two describes the data set under study and the econometric methodology used to estimate union effect. Section three examines the characteristics of schools that become organized. Section four presents estimates of the effect of academic unions on compensation and fringes. The paper concludes with a brief summary of the empirical results.

\section{Faculty Unionism in the U.S.}

Beginning in the late $1960^{\prime}$ 's academic faculty in the U.S. moved from essentially complete nonunion status to moderate levels of organization. In 1966, just 5,200 faculty were represented by unions; in 1970, 47,300 were represented by unions; in 1977 133,000 faculty were on organized campuses (Burton, table 7, o. 34).

The burst of organization was aided by several institutional developments: the passage of state laws making organization of public workers, including faculty at public colleges and universities, easier than in the past; changed attitudes toward unionization by faculty; the extension of NLRB election procedures to the university sector in 1969; and the general growth of unions of public employees.

With respect to the first development, in the 1960's and 1970's a large number of states enacted laws which either directly or indirectly made organization of faculties in the public sector easier. Some states enacted laws relating to the right of public employees in postsecondary educational Institutions to form unions and bargain collectively. Others passed omnibus public employee bills which include employees of state colleges and universities. Still others have de facto recognized the right of faculties to organize and have considered legislation to legalize the de facto situation, while yet others have treated the possibility of organization less favorably. 
The Education Commission of the States has categorized collective negotiations legislation along several dimensions, according to whether states have specific laws relating to postsecondary education and according to the nature of public employee legislation. From the Commission's classifications, five types of states can be distinguished: ${ }^{4}$

Group 1 - States which have specific legislation which deals with public employees in postsecondary educational institutions.

Group 2 - States in which there is no speciric mention of postsecondary education in an omnibus public employee bill but where by implication or interpretation postsecondary personnel and institutions are included.

Group 3 - States which have no collective negotiations legislation for postsecondary education but in which there are de facto postsecondary contracts or employee unit recognition and in which some legislative activity in respect to legalization of the de facto situation has taken place since 1970.

Group 4 - States in which there has been no notable legislation pending on the subject of collective bargaining for public employees in postsecondary education or where there was legislative activity since 1970 of an omnibus legislation level in which postsecondary personnel would have been included but where no legislation has been passed.

Group 5 - States which by statute prohibit any form of collective negotiations by public employees.

While not without problems, the Commission classification provides a rough grouping of the favorableness of state laws toward organization. Those with explicit collective bargaining laws have an institutional framework for recognition and negotiations, which should encourage unionization, while those without laws make recognition and bargaining an uncertain and riskier process. The states which outlaw public employee negotiations can be expected to have the least favorable environment for unionization.

With respect to attitudes, several surveys of the views of faculty in the late 1960's and early 1970's reveal surprising support toward unions on campus. In the 1969 American Council on Education survey of faculty, 59 percent 
thought that there was a place on campus for faculty collective bargaining and 47 percent.agreed that "faculty strikes can be legitimate action." In a 1972 survey, 43 percent of faculty agreed that "the recend growth of unionization of college and university faculty is beneficial and should be extended," [Ladd \& Lipset, Pp. 252-253]. While we lack survey evidence on attitudes in earlier years and have not investigated the potential causes of attitudinal changes, it is highly unlikely that faculty were as favorably inclined to organization in previous decades.

The extension of NLRB elections to private colleges and universities in 1969 eased the task of organizing those institutions. From 1969 to 1977 , colleges and universities held 127 representation elections of which 61 percent were won by the union. 5

Finally, and more speculatively, the growth of public sector organization in general may also be a potential cause of the growth of faculty unionism in the public sector. On the one hand, as increasing numbers of public employees become organized, the acceptability of organization rises. On the other, faculties may feel the need for a union to bargain for their interests against those of other public employees.

\section{Bargainers and Bargaining}

There are three main faculty unions: the American Federation of Teachers (AFT), which had 101 organized schools in 1977; the National Education Association (NEA) with 132 schools; and the American Association of University Professors (AAUP), which like other professional organizations threatened with unionization, responded by conducting representation elections and signing collective agreements; in 1977, the AAUP represented faculty in 41 schools and shared representation with the NEA on 4 (National Center of Education Statistics, table 4.166, p. 196). The NEA and AFT tend to be concentrated among two year colleges while the AAUP is found largely in four year institutions. 
On the employer side, most organized faculties are public institutions. In the sample covered in this paper, for example, 34.4 percent of public institutions were organized in 1976-77 compared to 16.7 percent of all institutions. 6

Faculty unions that negotiate with public institutions face the problem, endemic to the public sector, that budget decisions are made by legislators rather than by the administrators whom they face across the bargaining table. Because final funding authority rests with legislatures, academic managers may be willing to agree on certain increases, with the knowledge that if budgets are not raised, the contracts will not be effective. In Massachusetts, Worcester State College and Massachusetts College of Art negotiated contracts with the AFT in summer 1975 which provided for wage increases but because of legislative and executive decisions, no action was taken and the increase was not granted. The ability of unions to extract gains may depend on their influence on the legislature, rather than on negotiations with academic administrators.

Collective bargaining in academia has similarities and differences with bargaining in other sectors. In terms of topics, faculty unions evince considerable concern for job security and tenure provisions, much like other unions. Faculty unions have also sought additional fringe benefits, with the result that many two year and newer institutions have obtained fringes formerly exclusive to older, senior institutes [Duryea, Fisk, and Associates, p. 96]. Most faculty contracts contain grievance clauses [ibid., pp. 66-86], of a fairly standard type. In several negotiations unions have expressed concern for pay inequities, seeking greater standardization of rates -- a common union goal. The 1973 AAUP - Adelphi University contract established an "Inequity Fund" designed to reduce differentials among faculty. ${ }^{7}$. On the other hand, unlike nearly all American unions, which eschew a union role in operating establishments, 
academic unions are typically greatly concerned with governance, seeking to enhance the role of faculty in academic decision-making. In addition, faculty unions have rarely invoked the prime weapon of conflict of labor, the strike, with a result that bargaining often stretches over long periods of time. Whether the institutional and market structure in academe is likely to create the possibility of large or small union-induced increases in earnings is not clear. Public sector bargaining problems, and lack of a significant strike threat, may make faculty unions relatively weak.

\section{Data and Methodology}

This study examines the effect of faculty unions on academic pay using data on average compensation by institution from the annual compensation surveys of the AAUP. The AAUP data are obtained from an annual questionnaire distributed to academic institutions every year: the questionnaire requests detailed information on pay by rank for each school. The sample covered has increased over time: in 1964-65 the AAUP survey contained 755 schools; in $1977-78$, the survey included 2652 institutions. The AAUP data files used for the annual reports on the Economic Status of the Profession from 1970 to 1976 provide the basic compensation figures for this study. Relatively few faculties were organized in 1970 compared to 1976, giving valuable before/after unionization comparisons. In addition, a special file was created from the questionnaires of 1965 to provide figures for the period prior to the advent of any substantial unionization. The files for 1970-76 and 1965 were grouped into a single time series of cross-sections, with longitudinal information on a large number of institutions in different years. The size of the sample varies over time due to differences in responses. While the data set does not cover the entire universe of academic institutions, it offers a large and reasonably representative sample of colleges and universities.

The data tapes contain three measures of compensation which will be used in the empirical work: salaries; total compensation defined as salaries plus 
fringe benefits; and fringe benefits. When fringes are the dependent variable, total compensation is included as an explanatory variable in order to isolate the impact of unionism on the composition of the compensation package. In addition, they contain information on the degree granting status of schools: whether they grant Ph.D.'s, masters, bachelors, or two year degrees.

Information on whether or not a campus is covered by collective bargaining was obtained from the Directory of Bargaining Agents and Contracts in Higher Education (1 April 1977) of the National Center for the Study of Collective Bargaining in Higher Education which provides a "complete" count of trade union organization of academic enterprises. The year an institution was first listed as unionized was added to the tape as the appropriate indicator of unionization. Additional data on the characteristics of schools was obtained from a computer tape originally put together by $G$. Jackson of Stanford University. This tape includes information on SAT scores, family income of students, enrollments, and related factors which might affect compensation setting.

The sources of the data are described in detail in the notes to Table 1 .

\section{Estimating the Union Effect}

There are two basic ways in which the AAUP data set can be used to estimate the impact of trade unionism on faculty compensation: through cross-section regressions of compensation on unionization; or through more complex before/after models which exploit the longitudinal nature of the data to eliminate "unobserved" school factors.

The cross-section model is represented by:

$$
\operatorname{lnW_{it}}=a_{t} \mathrm{UN}_{i t}+b_{t} \vec{z}_{i}+\varepsilon_{i t}
$$

where $W_{\text {it }}=$ faculty pay in the $i^{\prime}$ th institution in year $t$ $\mathrm{UN}_{\text {it }}=$ dumm variable which takes the value 1 if the ith school is 
organized in year $t$

$\vec{z}_{i}=$ vector of control variables, assumed constant over time, whose effect is measured by the vector $b_{t}$

$\varepsilon_{i t}=$ residual.

Least square regressions will yield unbiased estimates of the union coefficient $a_{t}$ when $E\left(\varepsilon_{i t} U N_{i t}\right)=0$. When the residual is correlated with unionization, however, say because organization is more likely in high wage institutions, least squares will yield biased estimates. The availability of longitudinal data provides a means of correcting for the bias, essentially by permitting "before/after" comparisons of union compensation effects. Formally, we model the potential correlation between $\mathbb{U N}_{i t}$ and $\varepsilon_{i t}$ by dividing $\varepsilon_{i t}$ into two components: an omitted institution factor $h_{i}$ which is correlated with $\mathrm{UN}_{i t}$ (and the controls $\vec{Z}_{i}$ ) and a component independent of the variables in the equation, $v_{i t}$. This yields the following model:

$$
\ln w_{i t}=a_{t} u N_{i t}+b_{t} \vec{z}_{i}+h_{i}+v_{i t}
$$

If $Z_{i t}=Z_{i}$ and if $Z_{i}$ and $h_{i}$ have the same effect on $W_{i t}$ before unionism as afterwards, the comparable equation for the pre-union period is:

$$
\ln w_{i 0}=b_{i} \vec{z}_{i}+h_{i}+v_{i 0}
$$

where 0 relates to the period prior to unionization.

Subtracting (3) from (2) yields a simple before/after model

(4) $\operatorname{lnW}_{i t} / \mathrm{w}_{i 0}=a_{t} \mathrm{UN}_{i t}+\mathrm{v}_{i t}-\mathrm{v}_{i 0}$

When the effect of the various control variables differs over time, a more complex model is needed. If the effect of the omitted factor in the first period is $h_{i t}$ and if the effect in the second period is $h_{i 0}$ and if $h_{i t} \neq h_{i 0}$, the unobserved factor $h_{i}$ cannot: be eliminated by simple differencing. Letting $h_{i t}=\lambda h_{i 0}$, the model can be written (for two periods) as:

$$
\ln w_{i 0}=b_{0} \vec{z}_{i}+h_{i 0}+v_{i 0}
$$


(6)

$$
\ln W_{i t}=a_{t} U N_{i t}+b_{t} \vec{z}_{i}+\lambda h_{i t}+v_{i t}
$$

which becomes:

$$
\ln w_{i t}=\lambda \ln w_{i 0}+a_{t} U N_{i t}+\left(b_{t}-\lambda b_{0}\right) \vec{z}_{i}+v_{i t}-\lambda v_{i 0}
$$

Least squares estimates of equation (7) do not yield consistent estimates of the union effect because $E\left(W_{i 0} v_{i \theta}\right) \neq 0$. One can obtain consistent estimates by instrumenting $W_{i 0}$ on other variables, such as wages in another period. Alternatively, the extent of the bias on the union coefficient can be estimated using omitted variable bias formulae.

The principal independent variable in the analysis, the union status of schools, is measured in this paper in two different ways: with an $0-1$ dichotomous variable for whether a school is or is not organized in a given year; and with a more complex indicator of union strength, the years a school is organized. While years organized is unlikely to be an appropriate measure of union strength in industries that have long been unionized, the newness of faculty unionism makes it a potentially valuable measure of organizational strength. Years organized may be expected to have a positive impact on compensation for two reasons: because it takes time for faculties to obtain signed contracts and translate organization into wages and becausc institutions where union wage gains are more likely to be sizeable may tend to be organized earlier than those where unionism might have smaller economic effects. In empirical work, estimates are made of the effects on compensation of an $0-1$ union dumy variable, of years organized, and of the two variables together.

III. Who Gets Unionized?

Before examining the effects of unionism on compensation, it is important to consider the determinants of unionization and, in particular, the extent to which organization is or is not related to level of compensation prior to unionization. 
Table 1 records estimates of the relation between characteristics of institutions and union status in the AAUP sample as of 1976-77. Columns 1 to 3 give the $\beta$ coefficients from a logistic curve that estimates the impact of the characteristics of institutions, including compensation in 1970 (column 1) or 1965 (column 2) on organization:

(8) $\quad \operatorname{Pr}(U)=1 /(1+\exp -\Sigma \beta X)$;

where $\operatorname{Pr}(U)=$ probability of unionization in 1976

$\mathrm{X}=$ explanatory factors

Columns 4 to 6 give regression coefficients linking the number of years organized to the same set of independent vartilice. Four types of indencndent variables are used to explain the probability that a school is organized and the years organized: (1) measures of the characteristics of the school and its student body; log enrollment, to measure the impact of size; log of dollars per full-time enrollee, to measure wealth of the institution; the log of SAT scores of students, to measure the quality of the student body; three variables representing the position of the families of students in the income distribution, the percentage with incomes less than $\$ 5,999$, with incomes from $\$ 6,000$ to $\$ 8,900$ and with incomes from $\$ 9,000$ to $\$ 11,999$; and a series of dumny variables reflecting whether the school is public (vs. private); whether it is a Ph.D., masters, or 2 year granting institution (vs. a four year college); whether it is a primarily black school, a co-ed or female school or a religious school; (2) measures of the region in which the school is located, to capture the different attitudes toward unionism in different parts of the country; (3) measures of state legislation regarding organization, represented by dummy. variables for whether the state had legislation regarding post-secondary educational institutions, an omnibus public employee bill, de facto union recognition, or anti-union legislation (as described in section one); (4) measures of the log compensation prior to the advent of extensive unionism in two years: in 1965, when no institutions in the sample were organized, and in 1970, when relatively few were organized. The coefficient on wages in an early period will 
show whether or not unions have tended to organize high wage institutions, which would bias cross-section estimates of the union compensation effect upwards. Because some schools were organized in 1970, the equations with 1970 compensation, as controls are estimated in two samples: the full sample of schools, including those who were union in 1970, which could yield biased estimates of the link from compensation to organization because of the simultaneous effect of unionism on wages; and a sample excluding institutions already organized in 1970, which eliminates this problem. The sample sizes in columns 1 and 2 and in columns 4 and 5 differ because of the fewer matches between the 1965 and 1976 samples than between the 1970 and 1976 samples. The sample sizes in columns 3 and 6 are smaller than in columns 2 and 5 due to deletion of schools organized in 1970 .

The logistic and OLS estimates show that certain types of institutions are more likely to be organized than others. Organization is more frequent for: public than for private schools; for two year institutions relative to institutions granting higher degrees; for schools with lower SAT scores among students; and for institutions in the Northeast, especially relative to those in the South.

The coefficients on the dumm variables for the types of legislation indicate that the favorableness of state laws has a substantive impact on organization, with positive estimated effects for the more favorable laws and a negative estimated effect for the least favorable. Since the calculations include regional variables which are correlated with the legislation dumies, the result is a reasonably powerful one. While several of the legislative dumny variables have sizeable standard errors, as a set they enter the equations significantly.

Finally, in all of the calculations the base year wage variable is positively correlated with organization, indicating that unions have tended to organize faculties that had relatively high initial pay. The coefficient on the base period wage is considerably larger in columns 2,3 and 5 and 6 when 1970 compensation is used as the control than in columns 1 and 4 when 
Table 1: Logistic Curve and Least Squares Estimates of the Determinants of Faculty Unionismas of 1976-77

Logistic Curve Estimates of the Effect of Factors on Probability of Unionism
Least Squares Estimates of the Effect of Factors on Years Organized
(3)
(2)
(1)

Explanatory Variables

$$
\begin{array}{cccr}
-.03(.27) & -.15(.22) & -.06(.22) & -.16(.11) \\
2.63(.54) & 2.02(.43) & 2.27(.46) & 1.65(.20) \\
-.13(.79) & -.17(.62) & -.45(.66) & -.24(.26) \\
1.06(.51) & .86(.38) & .81(.40) & . .39(.16) \\
1.09(.90) & .66(.52) & .18(.57) & 1.06(.34) \\
-.37(1.45) & -.87(1.15) & -.67(.12) & -.04(.43) \\
.89(1.39) & .62(1.08) & .54(1.08) & .14(.32) \\
1.63(1.19) & 1.13(.91) & 1.01(.92) & .66(.27) \\
.14(.55) & .11(.44) & .10(.47) & .54(.17) \\
-.10(.61) & -. .55(.48) & -.13(.50) & .06(.16)
\end{array}
$$

(5)

(6)

Log (Dollars per Fu11-Time Enrollee)

\begin{tabular}{|c|c|c|c|c|c|c|}
\hline $\mathbf{N}$ & 615 & 889 & 863 & 615 & 889 & 863 \\
\hline -Ln (Likelihood Ratio) & 141.3 & 206.0 & 190.7 & -- & -- & -- \\
\hline $\mathrm{R}^{2}$ & - & - & -- & .43 & .39 & .39 \\
\hline $\begin{array}{l}\text { Mean (S.D.) of } \\
\text { Dependent Variable }\end{array}$ & $\begin{array}{l}.164 \\
(.371)\end{array}$ & $\begin{array}{l}.166 \\
(.372)\end{array}$ & $\begin{array}{l}.141 \\
(.349)\end{array}$ & $\begin{array}{l}.70 \\
(.178)\end{array}$ & $\begin{array}{l}.76 \\
(.196)\end{array}$ & $\begin{array}{l}.54 \\
(.154)\end{array}$ \\
\hline
\end{tabular}

Log (SAT Scores).

$-5.09(2.50)-7.87(2.04)-7.85(2.13)$

State Legislation Durmies

$\begin{array}{lrrrrrr}\begin{array}{l}\text { Specific Legislation } \\ \text { Omnibus Public }\end{array} & .54(.54) & .89(.46) & .59(.47) & .45(.20) & .57(.19) & .36(.15) \\ \begin{array}{l}\text { Employee Bill } \\ \begin{array}{l}\text { Defacto } \\ \quad \text { of Bargaining }\end{array}\end{array} & .53(.58) & 1.04(.48) & .75(.49) & .38(.22) & .57(.20) & .20(.17) \\ \text { Anti-union Legislation } & -1.59(1.13) & -.36(.88) & -.23(.89) & -.12(.19) & -.19(.19) & -.12(.15)\end{array}$

Region 2

Northeast

South

West

Compensation Variables

Log (Compensation 1965)

Log (Compensation 1970)

$$
\begin{array}{rrr}
1.81(.47) & 1.42(.40) & 1.51(.41) \\
-2.56(.80) & -2.10(.62) & -2.37(.69) \\
-1.09(.59) & -.86(.49) & -.89(.52)
\end{array}
$$

$$
3.10(2.02)
$$
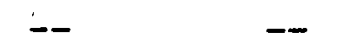

$1.61(.57)$

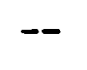

$$
8.81(1.75) 7.42(1.79)
$$

$1.34(.18)$

$-.22(.19)$

$-.23(.21)$

$.92(.18)$
.$- .24(.17)$
$-.11(.20)$

$.96(.14)$

$-.21(.14)$

$-.12(.17)$

Other Variables ${ }^{3}$

Three Durm!y Variables for Percent of Families of Students in Specified Income Classes

\section{Summary Statistics}


${ }^{1}$ School characteristics data are defined as follows:

Degree granting status based on AAUP definition as follows:

Ph.D.-granting = Category I: Institution offers the doctorate degree and conferred in the most recent three years an annual average of 15 or more doctorates covering a minimum of three non-related disciplines.

Masters-granting = Category II: Institution awards degrees above the baccalaureate but does not qualify for Category I. academic ranks

Two-year Institution = Category III: Two-year institution with

The deleted group consists of Category IIB: Institution awards only the baccalaureate or equivalent degree.

Public/private status from AAUP file.

The other school characteristics data were supplied by Gregory Jackson of the Stanford University School of Education and defined as follows:

Enrollment (measured by full-time equivalent students) and expenditure data for the 1970,1971, and 1972 acadenic years were compiled from the Higher Education General Institutional Survey conducted annually between 1966 and 1974 by the U.S. Office of Education. Enrollment data for years preceding and following this perios are not strictly comparable. The expenditures data used are under the category "Educational and General Expenditures: Total." The post-1970 expenditures were deflated to 1970 dollars with the Consumer Price Index. The mean amount of expenditures per full-time equivalent student for the 1970 to 1972 period was used in the computations.

The average academic ability of each relevant college's undergraduates was approximated by an estimate of the average combined verbal and math Scholastic Aptitude Test of the school's 1971 entering freshmen. These esimates (which involved some imputations) are discussed at length in Astin and Henson.

2 Includes additional dummy for not in U.S. in years organized regression.

Data relating to the income distribution of the families of undergraduate students obtained from G. Jackson's school characteristics tape. These data were collected from the "Tripartite Application" (i.e., "Institutional Application to Participate in Federal Student Financial Aid Programs"), a standard form ("1035) of the U.S. Office of Education. On the 1974 application (from which the data were obtained) each school was asked to estimate the number of full-time and half-time undergraduates from families in the following income ranges: $\$ 0-5,999, \$ 6,000-8,999$, $\$ 9,000-11,999$, and $\$ 12,000$ and above. Full-time and hàlf-time students were combined for this study by multiplying the latter by .50 to obtain the total number of full-time equivalent undergraduate students from families in each of the four
income classes.

Source: American Association of University Professors

G. Jackson

Education Commission of the States

National Center for the Study of Collective Bargaining in Higher Education. 
1965 compensation is used as the control. The positive regression coefficients on. In compensation prior to unionization in the equations highlight the need to control for initial compensation in analyzing the impact of faculty unions on compensation.

\section{Regression Analysis of Union Compensation Effect}

Estimates of the effect of faculty unionisn on In compensation are presented in this section using the cross-section and longitudinal models described earlier. The estimates suggest that faculty unionism raises wages, with schools organized earlier evincing a larger union impact than those with more recent unionism.

Least squares estimates of the cross-section relation between faculty unions and In of salaries or In of total compensation from 1970-1971 to 1976-1977 are given in Table 2. Columns 1 and 2 of the table list the total number of institutions in each year's sample and the number of organized institutions. Columns 3 and 4 give the coefficients and standard errors of the union dummy variable on In compensation and In salaries, respectively. Columns 5-8 present comparable information for the effect of unions on the compensation of faculty by rank. All of the regression calculations include the list of control variables given at the bottom of the table. The calculations for total faculty also include the percentage of faculty in various ranks, as specified in the table note.

The regression results show a significant union impact, which is larger on total compensation than on salaries and which is modestly larger for professors than for those in lower ranks. The greater impact of unionism on compensation than on salaries reflects the fact that unionism appears to raise fringes especially significantly (a pattern to be explored further in Table 5), possibly as a result of the greater weight given in a union setting to senior personnel who favor fringes. The larger impact of unionism on professorial than other salarics may also reflect the rolc of oldcr faculty in unionizcd marl.cts comparcl to competitive harkets therc vages n:c monc rosponsive to younger "marginal" employees. 
Table 2: Estimates of the Effect of Faculty

Unionism on Ln of Total Compensation and Ln of Salaries, Annual Cross-Sections, $1970-1977^{/ 1}$

Coefficients and Standard Errors

\begin{tabular}{|c|c|c|c|c|c|c|c|c|}
\hline Year & $\begin{array}{l}\text { Sample } \\
\text { for All } \\
\text { total } \\
\end{array}$ & $\begin{array}{l}\text { Size } \\
\text { Faculty } \\
\text { union } \\
\end{array}$ & $\begin{aligned} & \text { All I } \\
& \text { on } 1 \mathrm{~A} \\
& \text { salary }\end{aligned}$ & $\begin{array}{l}\text { aculty } / 3 \\
\text { on } 1 \mathrm{n} \\
\text { compensation }\end{array}$ & $\begin{array}{l}\text { Faculty } \\
\text { Prof }\end{array}$ & $\begin{array}{c}\text { by nanli } \\
\text { Assoc }\end{array}$ & $\begin{array}{l}\text { In Cow } \\
\text { Assist }\end{array}$ & $\begin{array}{l}\text { HSalluh } \\
\text { Instructors }\end{array}$ \\
\hline $70-71$ & 996 & 42 & $\begin{array}{l}.10 \\
(.01)\end{array}$ & $\begin{array}{l}.11 \\
(.02)\end{array}$ & $\begin{array}{l}.10 \\
(.03)\end{array}$ & $\begin{array}{l}.10 \\
(.02)\end{array}$ & $\begin{array}{l}.09 \\
(.02)\end{array}$ & $\begin{array}{l}.09 \\
(.02)\end{array}$ \\
\hline $71-72$ & 926 & 74 & $\begin{array}{l}.05 \\
(.01)\end{array}$ & $\begin{array}{l}.07 \\
(.01)\end{array}$ & $\begin{array}{l}.07 \\
(.02)\end{array}$ & $\begin{array}{l}.06 \\
(.01)\end{array}$ & $\begin{array}{l}.06 \\
(.02)\end{array}$ & $\begin{array}{l}.05 \\
(.01)\end{array}$ \\
\hline $72-73$ & 889 & 90 & $\begin{array}{l}.04 \\
(.01)\end{array}$ & $\begin{array}{l}.07 \\
(.01)\end{array}$ & $\begin{array}{l}.08 \\
(.02)\end{array}$ & $\begin{array}{l}.07 \\
(.01)\end{array}$ & $\begin{array}{l}.05 \\
(.01)\end{array}$ & $\begin{array}{l}.04 \\
(.01)\end{array}$ \\
\hline $73-74$ & 886 & 96 & $\begin{array}{l}.03 \\
(.01)\end{array}$ & $\begin{array}{l}.06 \\
(.01)\end{array}$ & $\begin{array}{l}.07 \\
(.01)\end{array}$ & $\begin{array}{l}.06 \\
(.01)\end{array}$ & $\begin{array}{l}.05 \\
(.01)\end{array}$ & $\begin{array}{l}.04 \\
(.01)\end{array}$ \\
\hline $74-75$ & 897 & 102 & $\begin{array}{l}.06 \\
(.01)\end{array}$ & $\begin{array}{l}.09 \\
(.01)\end{array}$ & $\begin{array}{l}.08 \\
(.01)\end{array}$ & $\begin{array}{l}.08 \\
(.01)\end{array}$ & $\begin{array}{l}.07 \\
(.01)\end{array}$ & $\begin{array}{l}.06 \\
(.02)\end{array}$ \\
\hline $75-76$ & 867 & 108 & $\begin{array}{l}.05 \\
(.01)\end{array}$ & $\begin{array}{l}.07 \\
(.01)\end{array}$ & $\begin{array}{l}.07 \\
(.01)\end{array}$ & $\begin{array}{l}.07 \\
(.01)\end{array}$ & $\begin{array}{l}.05 \\
(.01)\end{array}$ & $\begin{array}{l}.05 \\
(.01)\end{array}$ \\
\hline $76-77$ & 1221 & 195 & $\begin{array}{l}.04 \\
(.01)\end{array}$ & $\begin{array}{l}.05 \\
(.01)\end{array}$ & $\begin{array}{l}.05 \\
(.01)\end{array}$ & $\begin{array}{l}.04 \\
(.01)\end{array}$ & $\begin{array}{l}.04 \\
(.01)\end{array}$ & $\begin{array}{l}.03 \\
(.01)\end{array}$ \\
\hline
\end{tabular}

$1 \underline{1}$

The controls include the following variables: School Characteristics: (Log (Enrollment), Public, Ph.D. Granting, Nasters Granting, Rank 2 Year, Black, Female, Coed, Religious, Log (Dollars per Full-Time Enrollee). Log (SAT Scores), Percent of Students with Families in Specified Incore
Classes and Region (Northeast, South, West).

$1 \underline{2}$

Sample size is for all faculty -- slight variation by type of faculty. 13

Controls include the percentage of faculty who were professors, associate professors, and assistant professors.

Source: See notes to table 1 . 
The estimated coefficients on unionism differ noticeably over time, dropping fairly steadily from high levels of .11 (total) to .10 (professors) in 1970-71 to much lower levels of .05 (total and professors) by 1976-77. Because the cross-section samples change over time, there are two possible explanations for this pattern: a true time effect in which the inpact of unionisn is weakened in the declining market of the mid 1970's; or a "cohort effect" in which union effects have been smaller on more recently organized campuses. One way of differentiating between these two situations is to estimate the coefficient of unionism on a fixed set of schools over an extended number of periods. If there is a time (or "age") effect in which the union impact declines over time, the coefficient on unionism in the same set of schools will drop from the early years to 1977. If there is no such effect, the estimated union impact will remain the same. Table 3 presents the results of such calculations. It compares, for a fixed set of schools, the estinated effect of unionism in each year from 1970-71 to 1975-76 with the effect in 1976-77, when, according to Table 2, the union inpact was the smallest. Column 1 records the size of the sample of schools reporting in each base year. Columns 2 and 3 show the number unionized in the base year and in 1976-77. The coefficients on unionism in the base year and in 1976-77 are given in columns 4 and 5. In each year the comparison shows a decline in the union impact, ranging from .04 to .06 points. While this comparison controls for changes in the overall sample, it does not control for the growth of organization over the period and the changing schools in the union sample. To compare the effect of unionism on the same schools the unionism variable was decomposed into two variables: a dumm variable for schools organized in the base year and a separate dummy variable for those that became unionized thereafter. Column 6 gives the coefficient for the dumy variable for the schools organized in the base year. With the exception of 1970-71 the coefficients in column 6 are considerably larger than those on the union dumny variable in the preceding column, 


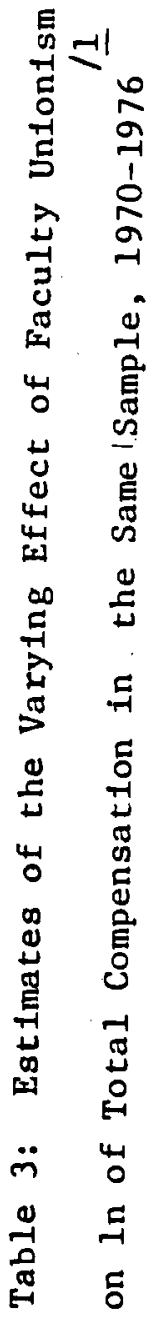

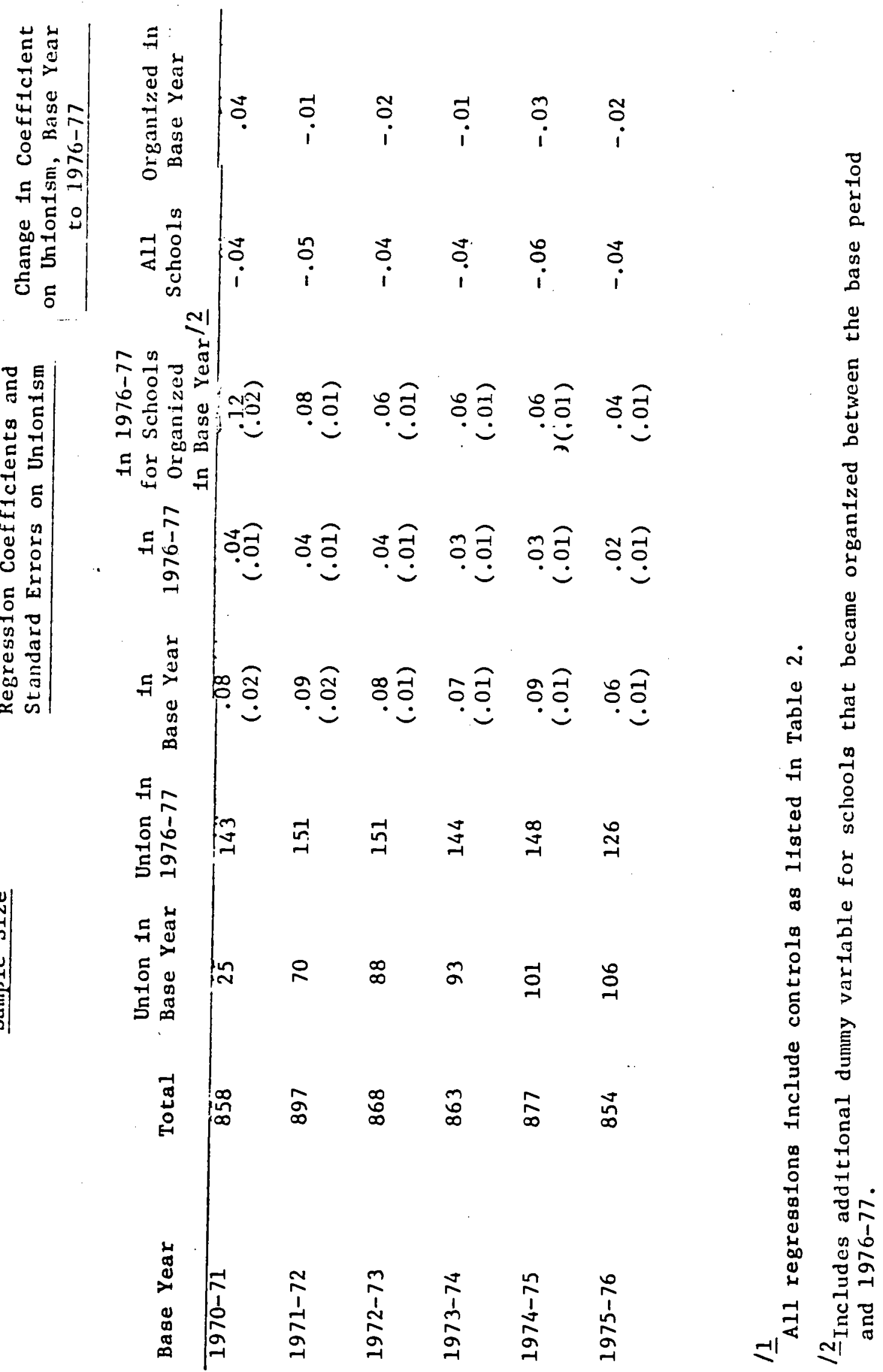


indicating that schools already organized in the base year had larger union wage effects. In several cases the estimates on the dummy variable for the newly organized schools is negative, indicating that, for whatever reason, there is a definitive differential effect of unionism on schools depending on when they were organized. While the estimated effect of unionism on the same schools shows a decline in the impact of organization from each base year to 1976-77, the drop is much attenuated from that found for all schools. At least half of the estimated drop in the overall union effect is due to the smaller impact of unionism on schools that were more recently organized rather than to a drop in the effect of unionism on a fixed set of organized institutions.

\section{Years organized and compensation}

The evidenca that the union wage effect in 1976-77 is greater for schools that were organized earlier than for those organized later suggests that the 0-1 union dumny variable may not be the best measure of the characteristics of organization that leads to higher wages. A potentially better variable may be the length of time organized. Accordingly, the regressions of Table 2 were re-estimated with the 0-1 dumny variable replaced with years organized as the prime explanatory factor and with both the dumm variable and years organized used as explanatory factors.

The results of these calculations are given in Table 4. Columns 1 and 2 record the mean years organized for all schools and for the unionized schools. Column 3 gives the coefficient on years organized when it is the sole measure of unionism while columns 4 and 5 record the coefficients on years organized and on the union dumy variable when both are included in the regressions. From 1970-71 through 1972-73 both variables enter significantly, roughly "dividing up" the union effect. Thereafter, the coefficient on years organized 
Table 4: Estimates of the Effect

of the Length of Period Organized on In of Faculty Compensation/ 1

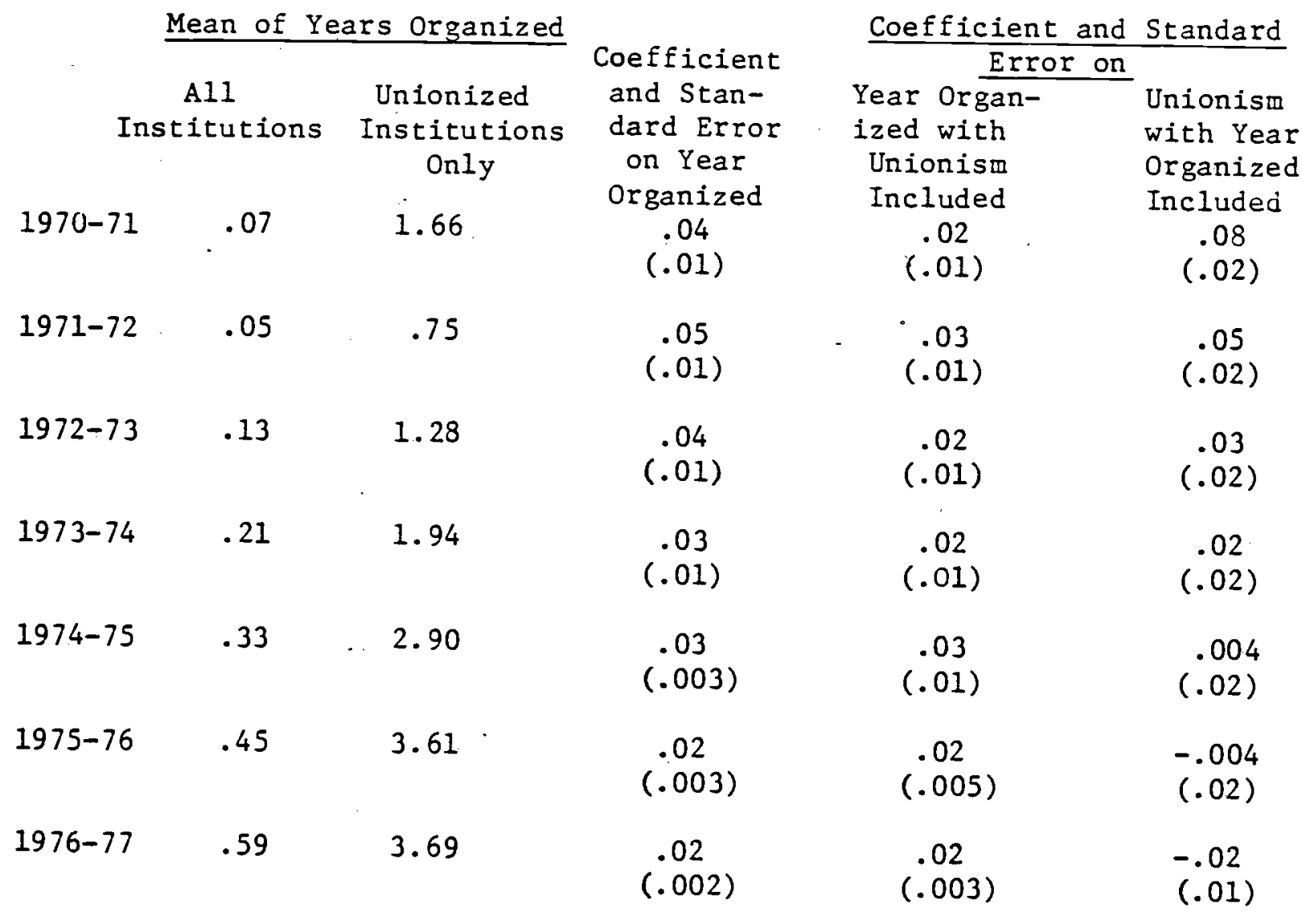

$\underline{11}$

All regressions include controls listed in Table 2. Sample sizes same as in Table 2 . 
tends to be much more significant, while that on the union dummy variable drops from .02 to an insignificant positive or to a negative value. In the later period, the years organized variable dominates the calculations, implying that newly organized schools obtained slight, if any, union wage gains in the mid 1970s. According to the regression coefficients for 1976-77, a school that was organized for only one year had no union wage effect whereas one organized for, say 5 years, would obtain a .08 gain. While it would be wrong to extrapolate the log-linear form beyond the period under study, as the effect of years organized is likely to level off as the variable increases, the results suggest much larger effects for schools that have been organized longer, with little or no union impact for those organized in recent years. Whether the observed pattern represents the effect of period of organization, the weakened market at the time of organization in the.1970's, or the unneasured characteristics of schools that lead to small or negligible union gains, cannot be determined from the data, requiring additional years of observation.

\section{Fringes}

The larger effect of faculty unionism on total academic compensation than on salaries suggests the value of a more detailed look at the area of pay where unions appear to make the biggest impact, fringes. In academe the most important fringes are insurance and pensions, with the university contribution to TIAACREFF often constituting a sizeable fraction of faculty pay. Faculty unions have tended to press for increased institutional contributions to these programs and to many other fringes as well.

The impact of faculty unionism on fringes is examined in Table 5, which records the results of regressing dollars of fringes on dollars of straighttime-pay, unionism, and the control variables used in preceding tables. By controlling for salary, the regressions estimate the effect of unions on the composition of the compensation package. Salary rather than total compensation is used as the independent variable because of the simultaneity problem due to 
the fact that fringes are included as part of compensation. Formally, the "structural" parameter for the impact of unionion on fringes, conpencation held Ifxed, can be derived from the regression using a simple simultaneous equation model. Let $S=$ salary, $F=$ fringes, $C=$ compensation $(S+F)$. Then, the impact of unionization on fringes, total compensation held fixed, is:

$$
F=a U+b C=a U+b(F+S) \text { so that } F=(a / 1-b) U+(b / 1-b) s
$$

Hence we can obtain the parameter a by dividing the coefficient on $U$ by 1 minus the coefficient on $S$.

The calculations reveal a significant impact of unionism on fringes except in 1970-71. As in the compensation and salary calculations, the impact of unionism does, however, change over time. It drops from 25-30 percent from 1971-75 to just 10 percent in 1976-77. Estimates (not reported in the table) of the union effect on a fixed sample of schools show that, as with total compensation, much of the drop is due to changes in the schools that are organized rather than to declines in the effect of unionism on the same school over time.

\section{Longitudina1 Mode1}

The longitudinal model developed in Section I uses wages prior to unionization to control for omitted factors that may be correlated with unionism and with later wages, biasing cross-section estimates of the union compensation effect. Table 6 presents least squares estimates of the longitudinal model with 1 of compensation in 1970 and 1 n of compensation in 1965 as indicators for the omitted factors. The least squares calculations ignore the problem noted earlier of the correlation between the residual and the initial period's level of pay. Experiments with instrumental variables, in which the lagged compensation was instrumented on 1 n compensation in other years, gave sufficiently similar results to suggest that the oLS calculations suffice to capture the effect of unionism in the data. Each regression in the table con- 
Table 5: Estimates of the Effect of Faculty Unionism on Dollars of Fringe Benefits for All Faculty with Dollars of Straight-Time Pay Held Fixed/ 1

\begin{tabular}{|c|c|c|c|}
\hline $\begin{array}{c}\text { Mean } \\
\text { Fringe }\end{array}$ & $\begin{array}{c}\text { Coefficient } \\
\text { (Standard Error) } \\
\text { on Unionism }\end{array}$ & $\begin{array}{l}\text { Structural } \\
\text { Parameters }\end{array}$ & $\begin{array}{l}\text { Elasticity } \\
\text { of Union } \\
\text { Effect }\end{array}$ \\
\hline $\begin{array}{c}(1) \\
\$ 1,252\end{array}$ & $\begin{array}{c}(2) \\
19(78)\end{array}$ & $\begin{array}{c}(3) \\
21\end{array}$ & $\begin{array}{c}(3) /(1) \\
.02\end{array}$ \\
\hline 1,419 & $296(69)$ & 333 & .23 \\
\hline 1,618 & $357(71)$ & 396 & .25 \\
\hline 1,818 & $401(71)$ & 449 & .25 \\
\hline 1,959 & $534(73)$ & 571 & .29 \\
\hline 2,133 & $358(72)$ & 415 & .19 \\
\hline 2,238 & $206(66)$ & 243 & .11 \\
\hline
\end{tabular}

11 Sample sizes same as in Table 2; all regressions include same controls as in Table 2, including percentage of faculty for various ranks. 
tains the full set of controls used in Table 2 but is limited to the sample of institutions reporting in the base year 1970 or 1965 as well as in the specified year. Because of this restriction the sample sizes are smaller than in Table 2 .

Lines 2-5 deal with the sample of institutions reporting in 1970 as well as in the later year. The first line gives the coefficient and standard error on the 0-1 union dumy variable in the absence of $1 \mathrm{n}$ compensation in 1970. The second line records the coefficient on unionism and on the $1 n$ of 1970 compensation obtained by addition of the latter variable to the regressions. Given the positive link between unionization and 1970 compensation obtained in Table 1 , addition of the compensation variable should reduce the estimated effect of unionism. This is clearly the case, with a sizeable drop in the estimated impact of unions of .03 to .05 points. The coefficients in line 2 are generally small and in several cases insignificant, implying that much of the cross-section relation between the 0-1 dummy variable and compensation is the result of the organization of institutions that were already high paying in 1970 rather than the effect of organization on compensation. A much less drastic change in the estimated effect of unionist is obtained in lines $4-5$, which record the results of rooressine In compensation on years organized with and without In compensation in 1970 as a control. While addition of 1970 compensation substantially reduces the impact of unionism (by $1 / 3$ rd to $3 / 4$ ths), years organized still obtains a significant positive coefficient in all but one year (1973-74). With the apparently better specification of the union variable, the positive correlation between base year pay and organization does not reduce the impact of unionism to the marginal levels given in line 3.

Lines 7-9 record the results of analogous experiments using in compensation in 1965 as the control variable. The results are strikingly different. When 1965 pay is the proxy for the omitted factor, the coefficient 
Table 6: Estimates of the Effect of Unionization on In of Faculty Compensation, Controlling for Compensation in 1970 or for Compensation in 1965, 1970-1977/ 1

$\underline{1970-71 \quad 1971-72 \quad 1972-73} \quad \frac{\text { YEAR }}{1973-74} \quad 1974-75 \quad 1975-76 \quad 1976-77$

Sample: Schools Reporting in 1970 and in Later Years Number of
Institutions $\begin{array}{lllllll}- & 805 & 764 & 749 & 744 & 720 & 858\end{array}$

2. Coefficient and Standard Error on Unionism in

$\begin{array}{cccccc}.07 & .07 & .05 & .08 & .06 & .04 \\ (.02) & (.01) & (.02) & (.01) & (.01) & (.01) \\ .02 & .02 & .01 & .05 & .02 & .00 \\ (.01) & (.01) & (.01) & (.01) & (.01) & (.01)\end{array}$

3. Basic Regression

Coefficient and

Standard Error on Unionism with

In Compensation in 1970 as Additional Control

4. Coefficient and Standard Error on Years Organized in Basic Regression

5. Coefficient and Standard Error on Years Organized with In Compensation in 1970 as Additional Control

Sample: Schools Reporting in 1965 and in Later Years

$\begin{array}{ll}6 . & \text { Number of } \\ & \text { Institutions }\end{array}$ 570 $\begin{array}{cccccc}-03 & .04 & .03 & .03 & .02 & .01 \\ (.01) & (.01) & (.01) & (.003) & (.003) & (.002)\end{array}$ $\begin{array}{cccccc}-03 & .04 & .03 & .03 & .02 & .01 \\ (.01) & (.01) & (.01) & (.003) & (.003) & (.002)\end{array}$ $\begin{array}{cccccc}-03 & .04 & .03 & .03 & .02 & .01 \\ (.01) & (.01) & (.01) & (.003) & (.003) & (.002)\end{array}$ $\begin{array}{cccccc}-03 & .04 & .03 & .03 & .02 & .01 \\ (.01) & (.01) & (.01) & (.003) & (.003) & (.002)\end{array}$ $\begin{array}{cccccc}-03 & .04 & .03 & .03 & .02 & .01 \\ (.01) & (.01) & (.01) & (.003) & (.003) & (.002)\end{array}$ $\begin{array}{cccccc}-03 & .04 & .03 & .03 & .02 & .01 \\ (.01) & (.01) & (.01) & (.003) & (.003) & (.002)\end{array}$

7. Coefficient and Standard Error on Unionisin in $\begin{array}{ll}.02 & .01 \\ (.01) & (.004)\end{array}$ .01
$(.01)$ .02
$(.002)$ .008
$(.002)$ .006
$(.002)$ Basic Regression

8. Coefficient and

Standard Error
on Unionism with 570

\section{5}

546

531

545

.08
$(.02)$

.08

(.03)

(.01)

.06
$(.02)$

.09
$(.01)$

.517

609

.10

.06

(.01)

.08

$(.02)$

(.01)

.05
$(.02)$

.05

$(.01)$

.09

.06

.04

In Compensation

in 1965 as Ad-

ditional Control

9. Coefficient and

Standard Error

.04

.07

$(: 04)$

.08
$(.01)$

.04
$(.01)$

.04

$(.004)$

.02
$(.003)$

.02

on Years Organ-

lzed in Basic

Regression

10. Coefficient and .04

Standard Error on (.01)

Years Organized

with in Compensa-

tion in 1965 as.

Additional Control

$1 \underline{1}$

All regressions include full set of control variables from iable 2. 
on the 0-1 union dummy drops by just .01 to .02 points, leaving a sizeable estimated impact, while the coefficient on years organized barely falls.

There are two possible reasons for these disparate findings: 1 . Since the schools reporting compensation in 1965 and in 1970 are somewhat different, the difference could reflect differences in the samples; 2 . Since faculty unionization increased rapidly in the $1970^{\prime}$ s, the result could reflect a tendency for schools facing organizing drives or potential organizing drives to raise pay with the hope of discouraging unionization. The possibility that the differences are due to differences in samples can be examined by comparing the effects of adding $\ln$ compensation in 1965 and In coupensation in 1970 to regressions covering the same sample of firms. The results of such an analysis for two years, 1976 and 1973, are given in Table 7, which records coefficients and standard errors on the union dumy variable and on years organized, entered separately, in In compensation regressions. Column (1) presents results without controlling for compensation in 1965 or 1970; column (2) gives results with in of 1970 compensation as the indicator of omitted factors; while colum (3) gives results with in of 1965 compensation as the additional explanatory factor. The regressions show clearly that differences in the samples do not explain the differential results: in the same set of schools, controlling for In compensation in 1970 reduces estimated effects of unions by considerably more than controlling for In compensation in 1965. This leaves open the possibility that compensation may have been raised in schools about to organize in the 1970's.

\section{A Full Sample Analysis}

The evidence that unionism has only a modest effect on compensation when In compensation in 1970 is entered as a control but a sizeable effect when In compensation in 1965 is entered leaves open the question of the mag- 
Table 7: Differential Impact of Adding 1n Compensation in 1970

and $1 n$ Compensation in 1965

on the Estimated Effect of Unionism in 1976 and in $1973 / 1$

Dependent Variable: In Compensation in 1976

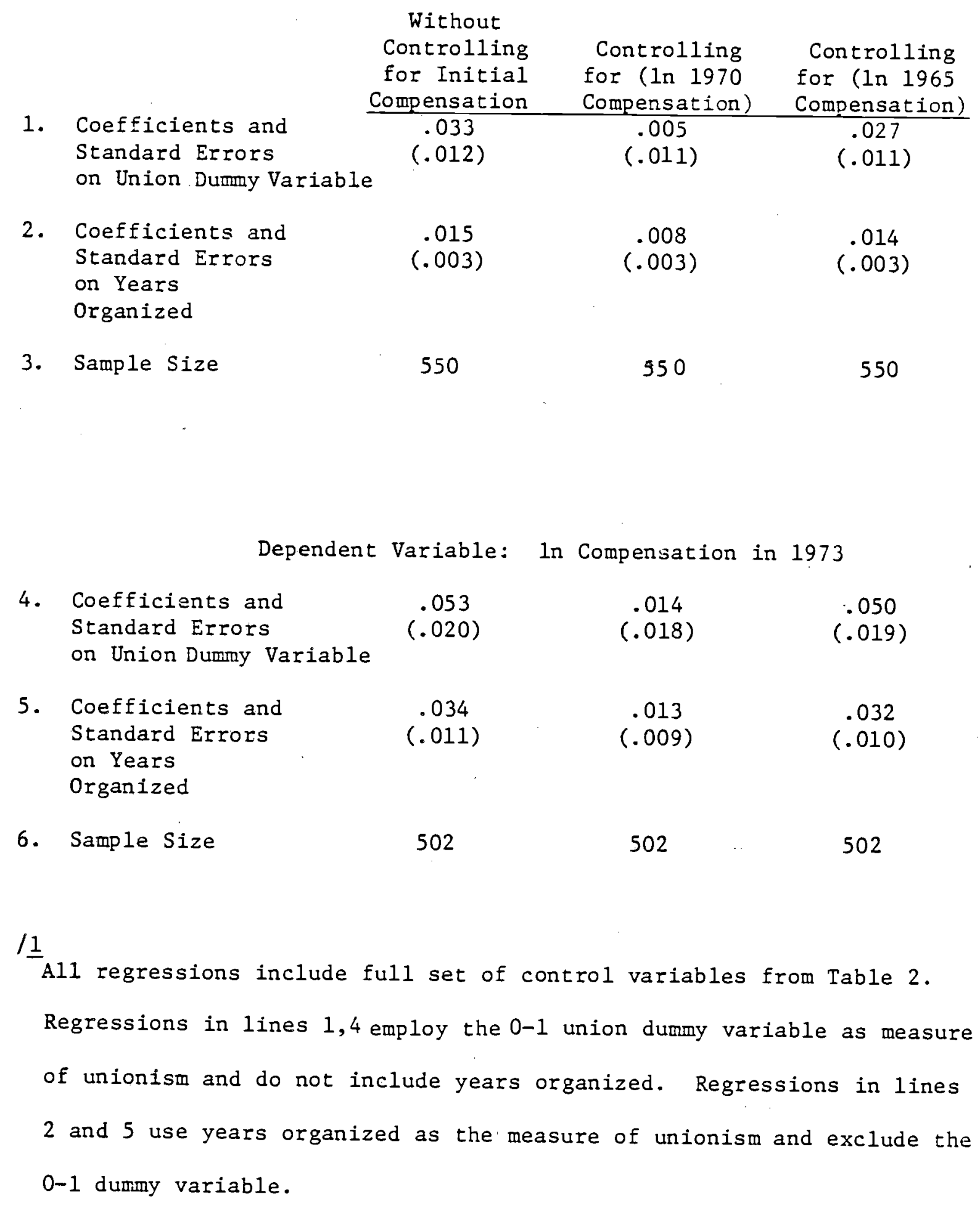


nitude of the union impact. To obtain an overall estimate of the union effect. corrected for omitted establishment factors, it is necessary to pool the information on $h_{i}$ from the full set of data over time. The easiest way to do this is to assume that $h_{i}$ has the same effect on In compensation in each year and add individual school constants to regressions of 1 n compensation on the various control variables, measures of unions, and time dumies. Such an analysis permits maximum use of the available observations, since all institutions that report to AAUP more than once are included in the calculations. The result of the regression is an estimate of the average effect of unionism on in compensation over the period, corrected for a constant institution effect. To the extent that $h_{i}$ is not constant over time, the regressions are likely to understate the union effect, since on the basis of the calculations in Table $6, \lambda$ is likely to be less than $1 . / 10$

Table 8 presents the results of such a regression analysis on the sample of institutions reporting at least twice in the AAUP survey over the period 1965, 1970-1977. Colums (1) and (3) give the coefficient on unionism and years organized on ln compensation without individual institution constants. Colums (2) and (4) record results with individual constants included as explanatory variables. The final. two colums present coefficients on the two measures of unionism, entered together, with and without the individual constants. The analysis shows a significant effect of trade unionism in all cases, with years organized bearing a much stronger relation to compensation than the 0-1 dummy variable, especially after addition of the school constants. The coefficient on the union dumy variable drops by about 80 percent upon addition of the constant (column 2 vs. column 1), while the coefficient on years organized falls much more modestly. In columns (5) and (6) addition of the school constants effectively wipes out the impact of the union dumny variable but does not alter the coefficient on years organized substantially. As the estimates in the table 
Table 8

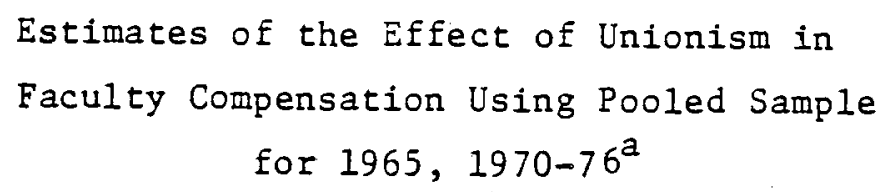

1. unionism

$(.004)$<smiles>C[Hg]</smiles>

$-$

$(.063$

.005

$(.004)$

.025

$(.001)$

.013

$(.001)$

(5)

(6)

2. years organized

\section{Other Controls}

3. school characteris tics ${ }^{b}$

4. region dummies (3)

5. year dummies (7)

6. school constants

\section{Summary statistics}

7. $\mathrm{R}^{2}$

8. $\mathrm{N}$

8436

8436

8436

8436

8436

8436 appendent variable is in compensation

b 'School characteristics, as in Table 2, in odd-numbered columns. The only characteristics to which we have data regarding changes over time are the degree-granting status of the school and the dummy variable for this are included in the even-numbered regressions. 
are based on a sample with 7 years of experience from the 1970's and just a single earlier year, the overall results are closer to those obtained by adding In compensation in 1970 to the regressions for individual years than to those obtained by adding In compensation in 1965. If institutions with potential for organizing raised compensation in the 1970's, the overall effect of faculty unions on compensation is likely to be understated compared to results that would be obtained if we had additional data for the 1960's. As they stand, the results do show a fairly substantial impact of years organized on compensation, with institutions that became union in, say, 1970, having compensation about 9 percent higher than they would otherwise have had. As noted earlier, however, the linear years organized effect should not be extrapolated beyond the limits of the sample: presumably the effect will decline as years organized grows.

\section{Conclusion}

This paper has examined the effects of faculty unionism on faculty compensation using different types of models and found that the estimated impact depends significantly on the model. Cross-section calculations yield sizeable estimates of the effect of faculty unionism on compensation, and on fringe benefits, which, however, differ over time and among institutions, and which show a stronger impact for years organized than for an $0-1$ dummy variable measure of unionism. A longitudinal model, which allows for a link between unionism and pre-union compensation levels and for a link between unionism and the characteristics that affect rates of change of compensation, yielded divergent estimates: with 1970 compensation entered in the regressions, the union effect was substantially reduced; with 1965 compensation entered, the effect remained sizeable. In a fixed effect model using all of the institutions and years, the average effect of years organized was significant 
and sizeable, but the effect of 0-1 union dumy variable declined greatly from cross-section estimates. The different results obtained in different years and with different samples and models is consistent with the divergent estimates of the effect of faculty unionism obtained in previous work, highlighting the need for more inclusive samples and estimating techniques. Perhaps the most surprising finding relates to the dependence of the union effect on years organized. This finding could result from three possible factors: 1. The increased ability of unions to win gains as time proceeds, at least over the span considered here; 2. Early organization of institutions with greater potential for gains in wages (as opposed to initially higher wages); 3. Greater difficulty in obtaining increases by unions organizing in the 1970's weakened academic market place than by ung ns organtzing earlier. If the results reflect the first factor, there are obviously much larger economic benefits from organization of remaining nonunion campuses than if they reflect. the second or third factors. 


\section{Footnotes}

$1 \underline{1}$

These estimates relate to schools rather than campuses. More than 500 campuses are reported as having bargaining agents. The figures on faculty unionism given by Burton relate to campuses; those given by the National Center of Education relate to schools.

12

The National Center for the Study of Collective Bargaining in Higher Education lists 74 schools as having voted against unionism as of 1977 compared to 343 who choose unionism.

$1 \underline{3}$

Birnbaum analyzed a sample of 88 matched union and nonunion campuses and found sizeable union wage advantages in 1972 and greater increases in wages on unionized campuses from 1968 to 1972. Morgan and Kearney analyzed a sample of 46 paired 4-year institutions, also finding larger monetary gains for unionized institutions, in this case from 1969-79 to 1974-75. Brown and Stone analyzed salary and compensation growth before and after collective bargaining on 37 campuses from 1970-71 to 1975-76 and compared the rates to those in the nation. They found "no significant impacts on salary, compensation, and promotions associated with the adoption of collective bargaining by college and university faculty."

$1 \underline{4}$

These categories are an amalgamation of those given on pp. 68-72 of the Education Commission of the States booklet. I have kept groups A, B and C from chart A as groups 1, 2 and 3; categorized the states from group $C$ of chart $B$ as having anti-union legislation (group 5) and placed the rest in group 4. 
$1 \underline{5}$

These figures are based on calculations from the computer tapes on representation elections of the NLRB.

16 Since the public institutions differ in various ways from the private institutions, these figures do not imply that public institutions are twice as likely to organize as private institutions.

17

This fund is described in Finkin, Goldstein, \& Osborne, pp. 72-7. The purpose of an inequity fund is "to raise the base salaries of those faculty members who fall below an established norm" (p. 72). For details see Collective Bargaining Agreement By and Between the Administration of Adelphi University and Adelphi University Chapter, American Association of University Professors, Sept. 1, 1973, Appendix B.

18

In particular, the percentage of schools unionized in the sample agrees well with the percentage reported for all schools.

19

In several calculations, the dummy variable for schools unionized after the base year obtained negative coefficients, indicating that the newly organized schools were obtaining lower compensation than nonunion schools. 110

When $\lambda$ is less than 1 , forcing it to be 1 will overstate the effect of the fixed factor, biasing downward the coefficient on the union variable. 
American Association of University Professors, "The Economic Status of

the Profession," various editors, The Summer Issue of the AAUP Bulletin.

American Council on Education, College and University Faculty: A Statistical

Description, (Washington, D.C.: June 1970).

Astin, Alexander and James Henson, "New Measures of College Selectivity,"

(UCLA: Higher Education Research Institute, mimeo).

Birnbaum, R. "Unionization and Faculty Compensation," Educational Record, 55, Winter, 29-33.

Brown, William and Courteney Stone, "Academic Unions in Higher Education: Impacts on Faculty Salary Compensation and Promotions, Economic Inquiry. July $19.77,385-396$.

Burton, S., "The Extent of Collective Bargaining in the Public Sector," in Public Sector Bargaining, edited by Benjamin Aaron, James L. Stevens and Joseph R. Grodin, forthcoming.

Duryea, E.D., Robert S. Fisk and Associates, Faculty Unions and Collective Bargaining, (San Francisco: Josey Bass, 1973).

Education Commission of the States, Collective Bargaining in Postsecondary Educational Institutions, Report no. 45, (Denver: March, 1974).

Finkin, Matthew W., Robert A. Goldstein \& Woodley B. Osborne, A Primer on Collective Bargaining for College \& University Faculty, (Washington, D.C.: AAUP, 1975).

Jackson, Gregory, Computer file on Characteristics of Colleges (Stanford Unirersity). Ladd, Everett and Seymour Martin Lipset, The Divided Academy (McGraw-Hill, 1975).

Morgan, David R. and Richard C. Kearney, "Collective Bargaining and Faculty Compensation: A Corporate Analysis", mimeo, University of Oklahoma.

National Center of Education Statistics, The Condition of Education, 1978 edition (Washington, D.C.: U.S. Govt. Printing office, 1978).

National Center for the Study of Collective Bargaining in Higher Education, Directory of Bargaining Agents and Contracts in Higher Education, (N.Y.: April 1, 1977). 